DOI: $10.36910 / 6775-2524-0560-2019-36-2$

УДК 621.444 .5

Булавка С.C.

Національний університет кораблебудування імені адмірала Макарова, Машинобудівний навчальнонауковий інститут.

\title{
ДОДАТКОВО КОРПУСНЕ ОХОЛОДЖЕННЯ БЕЗМАСЛЯНОГО ПОВІТРЯНОГО КОМПРЕСОРА ДЛЯ ЗМЕНШЕННЯ ТЕМПЕРАТУРИ ПОВІТРЯ
}

Булавка С.С. Додатково корпусне охолодження безмасляного повітряного компресора для зменшення температури повітря. В даній роботі автором розглянуто декілька прикладів різноманітних систем охолодження безмасляного повітряного компресора для зменшення температури повітря. Розглянуто дослідження в даній статті додаткове корпусне охолодження безмасляного повітряного компресора доохолоджувач 3 високою продуктивності гофрованого типу і охолоджуючий вентилятор великої пропускної здатності дозволяють спіральному компресора виробляти повітря з оптимальними характеристиками. Проаналізовано основні елементи безмасляного повітряного компресора для зменшення температури повітря та його застосування. Результатами даної роботи є застосування додаткового корпусного охолодження безмасляного повітряного компресора для зменшення температури повітря.

Ключові слова: компресор, безмасляний, охолодження, додаткове, зменшення температури.

Булавка С.С. Дополнительное корпусное охлаждения безмасляного воздушного компрессора для уменьшения температуры воздуха. Аннотация. В данной работе автором рассмотрены несколько примеров различных систем охлаждения безмасляного воздушного компрессора для уменьшения температуры воздуха. Рассмотрены исследования в данной статье дополнительное корпусное охлаждение безмасляного воздушного компрессора доохолоджувач с высокой производительности гофрированного типа и охлаждающий вентилятор большой пропускной способности позволяют спиральном компрессора производить воздуха с оптимальными характеристиками. Проанализированы основные элементы безмасляного воздушного компрессора для уменьшения температуры воздуха и его применения. Результатами данной работы является применение дополнительного корпусного охлаждения безмасляного воздушного компрессора для уменьшения температуры воздуха.

Ключевые слова: компрессор, безмасляный, охлаждения, дополнительное, уменьшение температуры.

Bùlavka S. S. Additional cooling of an oil-free air compressor housing to reduce air temperature In this paper, the author discussed some examples of different cooling systems and oil-free air compressor to reduce the temperature. Considered study in this article the additional Cooling oil-free air compressor dooholodzhuvach high performance corrugated type cooling fan and throughput allow air to produce scroll compressors with optimum performance. The basic elements of oil-free air compressor to reduce the temperature and its application. The results of this work is the application of the additional Cooling oil-free air compressor to reduce the temperature.

Keywords: compressor, oil-free cooling, additional, reducing the temperature.

Постановка проблеми у загальному вигляді та ї̈ зв'язок із важливими науковими та практичними завданнями. У компресорі 3 повітряним охолодженням для запобігання перегріву необхідно, щоб потік повітря, створюваний вентилятором, обдував його корпус. Потік повітря повинен нагнітатися безпосередньо на компресор. Повітря, що проходить через машинне відділення, не охолоджує компресор в достатній мірі.

Компресор з водяним охолодженням має водяну сорочку або мідний змійовик. Вода повинна циркулювати через систему охолодження, коли компресор працює.

Актуальною залишається проблема створення додаткового корпусного охолодження безмасляного повітряного компресора для зменшення температури повітря, що забезпечує надійну, безвідмовну роботу з мінімальними економічними та енергетичними затратами і це є актуальною задачею.

Аналіз останніх досліджень та публікацій. Розглянемо в даній статті декілька прикладів різноманітних систем охолодження компресорів [1-3].

«OF Kompressoren» німецька марка, що спеціалізується на розробці і виробництві безмасляних компресорів об'ємного принципу дії (спіральні і гвинтові). Дані компресори призначені для використання в харчовій промисловості, наприклад, на пивоварнях безмасляний стиснене повітря використовується для передавлювання рідини з однієї ємності в іншу.

Застосовувані технічні рішення спрямовані на унеможливлення потрапляння вуглеводневих домішок в стиснене повітря. У гвинтових компресорах використовується впорскування води в камеру стиснення, в гвинтовому блоці повністю відсутні масло-залежні елементи. При цьому, для підтримки якості використовуваної води, встановлюється система очищення і контролю наявності домішок. 
У спіральних компресорах застосовуються блоки стиснення, принцип роботи яких не допускає наявність масла в процесі стиснення повітря. Корпус компресори оснащується спеціальним звукоізолюючим матеріалом, який значно знижує рівень шуму. Багаторічний досвід виробництва $\mathrm{i}$ реалізовані проекти, дозволяють вирішувати різні завдання пов'язані з отриманням і очищенням безмасляного стисненого повітря.

Постановка завдання. Основною метою та завданням дослідження є додаткового корпусного охолодження безмасляного повітряного компресора для зменшення температури повітря. Дослідження в даній статті відноситься до обладнання насосних та компресорних агрегатів.

Завдання дослідження вирішується таким чином, що конструкція безмасляних компресорів являє собою зразок найкращого поєднання передової технології теплообмінників з конструкцією компресорів. Вона поєднує в собі малі втрати тиску і високоефективне охолодження. Стисле повітря проходить через мідні трубки з вбудованими ребрами. Труби охолоджуються зовні водою. Це гарантує ефективний теплообмін між повітрям і водою. Велика площа теплообміну спеціально розрахована, щоб забезпечити відмінне охолодження повітря при незначному підвищенні температури охолоджувальної води.

Виклад основного матеріалу дослідження. Система охолодження компресорів сприяє зменшенню роботи, що витрачається на стиснення повітря, знижує температуру всмоктуваного повітря, веде до підвищення продуктивності компресорів. Крім того, на клапанах і поршневих кільцях не утворюється нагар, оскільки при низькій температурі сповільнюються процеси окислення i розкладання масла. Система охолодження забезпечує умови для нормальної змащення циліндрів $\mathrm{i}$ безпечної роботи компресорів, так як температура повітря, що стискається підтримується значно нижча за температуру займання масла. [4]

Система додаткового корпусного охолодження компресора служить для відводу тепла від деталей і вузлів, що нагріваються при роботі, для охолодження повітря і охолодження газу, що стискається в ступенях компресора.

Безмасляний повітряний компресор представляє собою агрегат промислового призначення, що нагнітає повітря за допомогою гвинтової пари. Даний тип обладнання широко застосовують в промисловості при необхідності безперервно постачати стиснене повітря пневматичним системам. Гвинтове компресорне обладнання є економічним і сучасним обладнанням, яке характеризується помірним споживанням електричної енергії, простотою обслуговування і управління, а також довговічністю.

Безмасляний повітряний компресор - це агрегат оснащується повітряною, рідинної, або масляною системою охолодження. В результаті проходження процедури охолодження, повітря може містити масляні краплі, тверді частинки, а також водяні пари, що сприяє зносу обладнання. Тому, на виробництвах, де необхідно підтримувати високі стандарти чистоти стисненого повітря, використовуються повітряні і рідинні системи охолодження. Існують також моделі компресорів, оснащених ресивером і осушувачем, які поряд з очищенням від домішок повітря, забезпечують його рівномірну подачу і економію електроенергії. Такі моделі $\epsilon$ хорошим рішенням для компактних виробництв.

Гвинтові компресорні установки активуються за допомогою електродвигуна. Переміщення певного обсягу охолоджуючого речовини (холодоагенту) у формі газу, дозволяє точно відслідковувати процес охолодження в компресорі. Золотник, яким оснащений компресор, забезпечує зниження рівня припливу газу і потужності.

Гвинтовий компресор здатний працювати в режимі холостого ходу, що дозволяє знизити споживання електроенергії в п'ять разів, а також максимально скоротити знос деталей через відсутність зайвих включень електричного двигуна [3-4].

Даний вид компресора, на відміну від поршневих компресорних установок, не викидає зайве повітря. Крім того, гвинтовий компресор виробляє стиснене повітря помірної температури, так як на кінці стиснення температура низька.

За технічними характеристиками безмасляні повітряні компресорі порівнянні з поршневими агрегатами промислового класу i актуальні для підприємств, на яких необхідно підтримувати безперервний процес виробництва.

Основний принцип роботи безмасляних гвинтових компресорів такий же як у масляних компресорів, тільки в цьому випадку тут не використовується масло, тільки повітря! Т.к тут не 
впорскується масло під час стиснення, стиснення проводиться зазвичай в два етапи. Тому що якщо ми будемо стискати повітря в одну стадію наприклад з 1 до 7бар, він стане дуже гарячим.

Ступінь 1 стискає повітря до декількох бар (наприклад 2,5бар). Повітря тут дуже гарячий, тому він подається спочатку через проміжний охолоджувач перш ніж вступити в другий щабель. Ступінь 2 стискає повітря далі з 2,5бар до необхідної величини, наприклад до 7 бар. Зазвичай 2 ступені вбудовані на 1 редукторі з 1м ел. двигуном який приводить їх в рух одночасно.

Якщо вам потрібен 100\% безмасляне повітря і у великій кількості, безмасляний гвинтовий компресор то що вам потрібно. Звичайно ж, тут мова і про велику ціну, але якщо Вам дійсно потрібен 100\% безмасляний повітря, то у Вас немає вибору. Переваги: 100\% повітря без масла.

Недоліки:

- Дорожчий, ніж масляний тип.

- Обслуговування / ремонт складніший процес і дорожчий, ніж у масляного типу компресора.

- Більш гучний, ніж масляний тип.

Безмасляні компресори мають багато областей застосування. Це харчова, хімічна промисловість, фармацевтика, радіоелектроніка та виробництво напівпровідників ,. Гвинтові безмасляні компресори можна поділити на безмасляні компресори з уприскуванням води в камеру стиснення, гвинтові компресори сухого стиснення.

Безмасляні повітряні компресори ідеально підходять для споживачів стисненого повітря в таких чутливих до якості повітря галузях, як фармацевтика, харчова та напівпровідниковий виробництво, де потрібно абсолютно безмасляне стиснене повітря. У гвинтовому безмасляні компресори ZS 37+ попадання масла в контур стиснення неможливо, що означає отримання спочатку безмасляного стисненого повітря. Завдяки безмасляному повітрю потрібно менш дороге наступне очищення повітря. Крім того, так як компресори даної серії проектувалися для безпечного і надійного стиснення великих обсягів безмасляного повітря, вони енергетично ефективні як при повному навантаженні, так і в переривчастому режимі [5, 6, 7б 9-11].

Використання двоступеневого компресорного блоку гарантує дуже низьку питому витрату енергії. Доступні версії компресорів з прямим або кліноременним приводом, а також опціонально 3 частотним перетворювачем. Вали укомплектовані спеціальними кільцями ущільнювачів 3 двоступінчастим охолодженням. Ця система гарантує найбільшу експлуатаційну надійність. На високоточні ротори нанесено довговічну захисне покриття, що запобігає корозії.

Гвинтова компресорна щабель 3 достатнім запасом міцності роликових підшипників має високу якість і міцність, забезпечує найбільш тривалі терміни служби навіть в найжорсткіших умовах експлуатації. Спеціальні підшипники усувають необхідність додаткової компенсації осьових навантажень.

Розглянемо Компресор Atlas Copco ZS 37+, який наведено на рис. 1 [8].

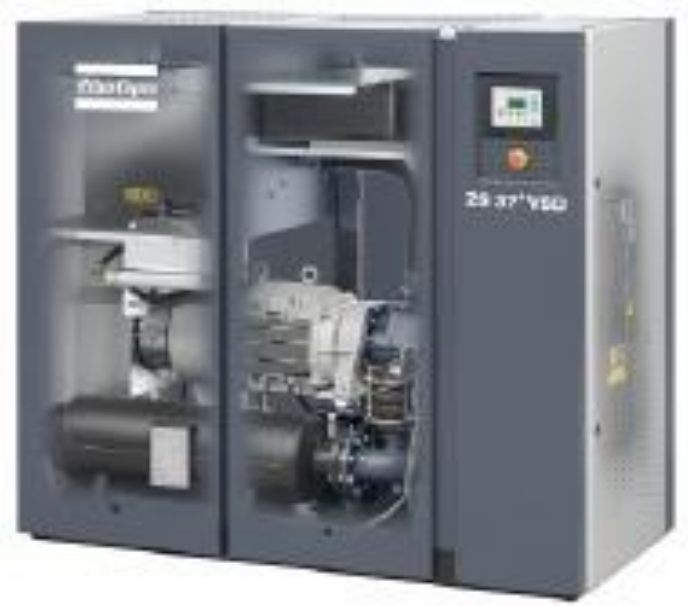

Рис. 1. Компресор Atlas Copco ZS 37+

Багато галузей промисловості використовують компресори в виробничому процесі і тому зможуть отримати користь з енергозберігаючих властивостей гвинтових компресорів. В основному 
це можуть бути муніципальні і промислові станції водоочистки, де на компресори доводиться 70\% сумарних витрат електрики. Мільйони бактерій розмножуються на органічних відходах, перетворюючи їх в діоксид вуглецю, азот і воду. Оскільки для життєдіяльності бактерій необхідний кисень, значні кількості повітря продуваються через аеротанкі.

Незалежна організація TÜV провела порівняння характеристик нового безмасляного повітряного компресора ZS з характеристиками трилопатевого компресора згідно з міжнародним стандартом ISO 1217, ред. 4. Результати показали, що ZS на 23,8\% ефективніше, ніж трилопатевий компресор при тиску 0,5 бар (хат.) / 7 фунт. / Кв. дюйм (ман.), і на 39,7\% при тиску 0,9 бар (хат.) / 13 фунт. / кв. дюйм (ман.). Висока ефективність ZS обумовлена головним чином технічно досконалої гвинтовий технологією.

Іншими особливостями, що гарантують високу ефективність і надійність, $є$ інтегрований редуктор, система мастила і інноваційна конструкція, яка об'єднує всі окремі компоненти в готове до роботи обладнання $[6,8]$.

Atlas Copco $є$ світовим лідером в області виробництва компресорів, будівельного i гірничошахтного устаткування, промислового інструменту і складальних систем. Група пропонує інноваційні продукти і послуги, що забезпечують зростання продуктивності замовників. Група Atlas Сорсо, заснована в 1873 році, має представництва в більш ніж 170 країнах світу. Штаб-квартира компанії знаходиться в Стокгольмі, Швеція, і має представництва в більш ніж 170 країнах. У 2009 році в Atlas Сорсо налічувалося 30000 співробітників, дохід компанії склав 64 млрд. Шв. крон (6 млрд. євро).

Департамент безмасляних компресорів займається розробкою, виробництвом і збутом безмасляних повітряних компресорів для всіх галузей промисловості по всьому світу, де якість повітря має життєво важливе значення, а також маслонаповнених компресорів для «менш вимогливих» галузей промисловості. Основна увага приділяється створенню систем оптимізації повітря, післяпродажного обслуговування і розробці технічних рішень 3 контролю якості повітря 3 метою підвищення продуктивності наших замовників. Штаб-квартира підрозділу і головний виробничий центр розташовані в м Антверпен, Бельгія [8].

Безмасляні гвинтові сходи ZS 37+ працюють 3 набагато більшою швидкістю, ніж маслозалежні ступені і тому висока температура повітря, що виникає в ході компресії, розсіюється по-іншому.

Спеціальна компресорна щабель ZS 37+ та концепція додаткового охолодження $\epsilon$ центральним елементом конструкції. Обидва компоненти були розроблені для забезпечення граничної безпеки і максимальної ефективності - ідеально підходять для областей застосування 3 високими вимогами.

Висновки і перспективи подальших розвідок. Таким чином, Безмасляний повітряний компресор представляє собою агрегат промислового призначення, що нагнітає повітря за допомогою гвинтової пари.

Система додаткового корпусного охолодження компресора може бути декількох типів: повітряне, водяне. При розробці компресора $з$ додатковим водяним охолодженням застосовуються технології спрямовані на повне виключення можливості попадання охолоджуючої рідини в внутрішній контур. При цьому за рахунок використання сухої градирні, вимоги до вентиляції приміщення знижуються, так як охолодження вимагає тільки електромотора, i частотного перетворювача.

Технології, застосовані в даному обладнанні, знизили витрати на технічне обслуговування. Основне технічне обслуговування такої системи додаткового корпусного охолодження зводиться до заміни всмоктуючого фільтру і обслуговування системи власної водопідготовки.

Результатами дослідження $є$ додаткового корпусного охолодження безмасляного повітряного компресора для зменшення температури повітря.

Безмасляні повітряні компресори ідеально підходять для споживачів стисненого повітря в таких чутливих до якості повітря галузях, як фармацевтика, харчова та напівпровідниковий виробництво, де потрібно абсолютно безмасляне стиснене повітря.

\section{Список бібліографічних посилань}

1. Система - охлаждение - компрессор - [Електронний ресурс].- Режим доступу: http://www.ngpedia.ru/id426273p1.html

2. Безмасляные компрессоры of kompressoren - [Електронний ресурс]. Режим доступу: http://mppnik.ru/publ/1542bezmaslyanye-kompressory-obemnogo-principa-deystviya-of-kompressoren.html 
Луиьк, 2019. Випуск № 36

3. Винтовые компрессоры безмасляные BOGE - [Електронний ресурс]. Режим доступу: http://www.immertechnik.ru/downloads/so.pdf

4. Федоров О.Г. Компресорні станції та компресорні установки. Навчальний посібник. Посібник для студентів, що навчаються за спеціальностями 7.090508 та 7.090.522 напрямку Енергомашинобудуваня. Одеська національна академія харчових технологій. 2013

5. Винтовые компрессоры и компрессорные установки. - [Електронний ресурс] . Режим доступу: http://www.intechgmbh.ru/screw_compr.php

6. Atlas Copco Безмасляные воздушные компрессоры. - [Електронний ресурс]. Режим доступу: http://промкаталог.pф/PublicDocuments/1109179.pdf

7. Козорез А.І. Компресорні станції та компресорні установки.- ОДАХ. 2007. 71.

8. Atlas Сopсо представляет энергосберегающие винтовые воздуходувки. [Електронний ресурс] . Режим доступу: http://profitoolinfo.ru/ru/news/3483/

9. Тиранов С.В. Системы снабжения предприятий сжатым воздухом: Учеб. пособие. Нижнекамск: НХТИ, 2010.

10. Трубаев П.А., Беседин П.В., Гришко Б.М. Проектирование систем воздухоснабжения промышленных предприятий: Учеб. пособие. Белгород: БелГТАСМ, 2001. 122 с.

11. Рахмилевич 3.3. Компрессорные установки.-М.:Химия, 1989. 272c.

1. System - cooling - compressor - [Electronic resource] -- Access mode: http://www.ngpedia.ru/id426273p1.html

2. Oil-free compressors of kompressoren - [Electronic resource]. Access mode: http://mppnik.ru/publ/1542-bezmaslyanyekompressory-obemnogo-principa-deystviya-of-kompressoren.html

3. Oil-free screw compressors BOGE - [Electronic resource]. Access mode: http://www.immertechnik.ru/downloads/so.pdf

4. Fedorov OG Compressor stations and compressor installations. Tutorial. Guide for students studying in the specialties 7.090508 and 7.090.522 in the field of power engineering. Odessa National Academy of Food Technologies. 2013

5. Screw compressors and compressor units. - [Electronic resource] . Access mode: http://www.intech-gmbh.ru/screw_compr.php

6. Atlas Copco Oil-free air compressors. - [Electronic resource]. Access mode: http: // promkatal.rf/PublicDocuments/1 109179.pdf

7. Kozorez AI Compressor stations and compressor installations. - ODAH. 2007. 71.

8. Atlas Copco introduces energy-saving screw blowers. [Electronic resource] . Access mode: http://profitoolinfo.ru/en/news/3483/

9. SV Tiranov Systems of supply of the enterprises with compressed air: Textbook. allowance. Nizhnekamsk: NKTI, 2010.

10. PA Trubaev, PV Besedin, BM Grishko. Designing of systems of air supply of the industrial enterprises: Textbook. allowance.

Belgorod: BelGTASM, 2001. 122 p.

11. Rakhmilevich Z.Z. Compressor installations. - M .: Chemistry, 1989. 272s. 